May 14/37. A. Shot Feb. 9/40 (-3 yr.) in Texas (310-0970).

May 14/37. A. Shot Feb. 5/38 (-1 yr.) in Nebraska (410-1004).

May 20/37. A. Shot Jan. 22/38 (-1 yr.) in Oklahoma (364-0971).

May 27/37. A. Shot Jan. 22/38 (-1 yr.) in Nebraska (412-0974).

May 27/37. A. Shot Jan. 2/39 (-2 yr.) in Oklahoma (345-0980).

May 27/37. A. Shot Jan. 19/38 (-1 yr.) in S. Dakota (432-0975).

June 9/37. A. Shot Feb. 24/38 (-1 yr.) in Texas (330-0960).

June 9/37. A. Miscellaneous cause, Dec. 1/38 (1 yr.) in Neb. (410-0985).

June 23/37. A. Found dead April 15/38 (-1 yr.) in N.D. (465-0964).

Aug. 31/37. A. Shot Dec. 2/38 (1 yr.) in Oklahoma (345-0981).

May 11/38. A. Shat July/41 (3 yr.) in Alberta (521-1122).

May 11/38. A. Shot July 8/39 (1 yr.) in Alberta (514-1143).

May 11/38. A. Shot July/41 (3 yr.) in Alberta (513-1140).

May 11/38. A. Shot June 10/44 (6 yr.) in Alberta (521-1140).

May 18/38. A. Shot Aug. 26/39 (1 yr.) in Alberta (521-1122).

May 18/38. A. Shat May 30/41 (3 yr.) in Alberta (532-1105).

May 19/38. A. Shot March 30/44 (-6 yr.) in Kansas (372-0981).

May 19/38. A. Shot March 24/39 (-1 yr.) in Kansas (373-0980).

May 21/38. A. Shot March 6/39 (-1 yr.) in Texas (335-0982).

June 14/38. A. Shot early April/40 (-2 yr.) in S.D. (438-0998).

July 9/38. A. Shot Jan. 23/39 (-1 yr.) in Oklahoma (345-0974).

In same or adjacent quadrant: Same year, 39 shot, 3 trapped, 1 killed by owl, 1 miscellaneous; at one year, 2 shot, 1 trapped; at two years, 2 shot.

Elsewhere in Saskatchewan: Same year, 45 shot, 7 trapped; at one year, 15 shot, 1 caught by hand; at two years, 5 shot; at three years, 2 shot; at four years, 1 shot; at five years, 1 shot; at nearly nine years, 1 shot.

\title{
SOME 1968 SOUTHERN ALBERTA BIRD OBSERVATIONS
}

\section{by Wayne W. Smith and Cleve R. Wershler, Calgary}

The purpose of this article is to put on record some interesting observations made in southern Alberta in 1968. Most of the observations were made in the Calgary area. On a few occasions, one or more of the following people were with us - Stu Alexander, Keith Seely, Red Mason, Ian Halladay, Jack Shier, and Garry McKay. In addition, Dave Thomae and Tom Sadler provided several of their personal observations. The observations show the variety and quality of southern Alberta for bird watching. Even a major city like Calgary has areas of great quality.

Pied-billed Grebe (Podilymbus podiceps). On June 13, one adult was found at the first Vermilion Lake, Banff National Park (Dave Thomae, pers. comm.). The next evening (June
14) a nest with seven eggs was found. On July 3 , one adult and 6 young (2-3 weeks old) were found on a slough about 10 miles north of Turner Valley (25 miles southwest of Calgary). These two records appear to be the first nestings recorded of this species in the mountains and foothills of Alberta.

Night Heron (sp.?) For three days (August 19-21) an immature heron was seen in Calgary (Inglewood). On one of these days we approached to within 25 feet of the bird, getting an excellent view, as it sat in a large willow. We observed the bird through 7-power binoculars and made field notes from which the following points were taken:

1. conspicuous yellowish bill (short and very thick for a heron). 
2. yellowish legs of moderate length. greyish-brown upperparts (darkest on wings) spotted with white, with the spots becoming very small on crown.

whitish underparts, heavily streaked with greyish-brown.

- heavily streaked, whitish neck with brownish wash on upper surface.

The bird was seen to stretch out its heck several times, a habit which we had not observed in night herons beore. After comparing our field decription with a specimen of an immature Black-crowned Night Heron (Nycticorax nycticorax) at the University of Calgary, both of us feel that there is a good possibility that the night heron observed was a Yellow-crowned Night Heron (Nyctanassa violasea).

Trumpeter Swan (Olor buccinator). On August 24 and 25, a single adult was occupying a large slough about two miles north of Reesor Lake (in the Alberta section of the Cypress Hills.) No other swans were seen.

Gadwall (Anas strepera). A pair was seen on May 31 at Vermilion Lakes, Banff National Park (Dave Thomae, pers. comm.). This species has been seen only infrequently in the mountains of Alberta.

Cinnamon Teal (Anas cyanoptera). Cinnamon Teal are considered to be scarce summer residents in Alberta, with few records from the province (The Birds of Alberta, 1966). However, in 1968 there were reports of Cinnamon Teal from six areas in southern and central Alberta.

1. Between April 26 and May 29 the Vermilion Lakes area of Banff National Park was inhabited by as many as five pairs at one time. There was a gap in observations from this area until mid-June, when several pairs were again seen (Dave Thomae, pers. comm.)

2. On May 11, 17 were seen in the Blizzard-Frank Lakes area.

3. On May 12,8 were seen 2 miles south of Calgary. On August 17, one male was in the same general area.
4. On May 19, a pair was seen at Beaverhill Lake (40 miles east of Edmonton) by the Edmonton Bird Club and Wayne W. Smith.

5. One pair was present in the spring near Strathmore. One female teal with a brood a six was seen on the same slough in the summer; but was not positively identified as a Cinnamon Teal (Tom Sadler).

6. Between mid-July and mid-August 25 Cinnamon Teal were seen on sloughs immediately northeast of Calgary.

The large number of sightings of this species in the Calgary area in 1968 might be attributable to the generally dry spring creating a more suitable habitat, allowing a range expansion into the area from the south.

Ring-necked Duck (Aythya collaris) On July 3, three pairs were present on a slough 10 miles north of Turner Valley. During July, one female and her brood of seven were present in the Scott Lake area, ca. 50 miles west of Calgary (Tom Sadler). On July 10, three males were seen on a lake about 45 miles northwest of Calgary. All three sightings were in the foothills section of Alberta and suggest that this species is spreading southwards along the foothills as a breeding species.

Hooded Merganser (Lophodytes cucullatus). On May 22, a male was seen in Calgary (Inglewood). It is unusual to observe this very rare summer resident away from its mountain habitat so late in the spring.

Sharp-shinned Hawk (Accipiter striatus). On September 28, 15 adult birds of this species passed an observation point on the summit of a cliff in the Bighill Springs valley (15 miles northwest of Calgary) in a time period of one-half hour. The birds, following a common flight-line, passed within a few feet of us. Although Sharp-shinned Hawks are fairly common migrants in the Calgary region, such a defined movement is not often recorded.

Ferruginous Hawk (Buteo regalis). On April 7, one dark phase bird was 
seen just east of Calgary and on September 29 an almost completely melanistic individual was observed near Cochrane. Dark phase Ferruginous Hawks are rare in Alberta.

Prairie Falcon (Falco mexicanus). On May 19, one was sailing high in a northerly direction over Beaverhill Lake and appears to be the farthest north that mexicanus has so far been recorded in Alberta.

Peregrine Falcon (Falco peregrinus). On April 17, one flew north, at a great height, over southwest Calgary. On August 17, an immature male came slowly sailing south at about 25 feet over the margin of Frank Lake (30 miles south of Calgary). In Alberta, Peregrines are now extremely rare and are on the brink of extinction as a breeding species.

Knot (Calidris canutus). On May 11, three were seen at Frank Lake, and two were recorded just northeast of Calgary in August. The Birds of Alberta states that Knots pass over the southern prairies without stopping, and occur as scarce but regular migrants in central Alberta about late May or early June in spring, and the latter part of September in fall. This makes the above two records exceptional in two respects - date and location.

Western Sand piper (Ereunetes mauri). On August 17, one bird, in breeding plumage, was found at Frank Lake, in company with other shorebirds. All important field marks, particularly the distinctive bill, were noted and compared to those of the three other "peeps" in close proximity. The nature of the shore and bird allowed an approach, with a $30 \mathrm{x}$ 'scope to within 30 feet. This was the third or fourth Alberta sighting of the Western Sandpiper, a species that is listed as "hypothetical" for the province. The observers were Red Mason of Toronto, who is familiar with this species, and Wayne W. Smith.

Franklin's Gull (Larus pipixcan). On July 3, several hundred adults were observed in the area of Gorge Creek-Sheep Creek (20 miles west of
Turner Valley). This is in the mountains of Alberta, where it has been reported only infrequently.

Sabine's Gull (Xema sabini). On May 18 one was seen flying north over the firsit Miquelon Lake (40 miles southeast of Edmonton). The Birds of Alberta gives the status of the Sabine's Gull in this province as a rare, erratic wanderer; but conversations with Edmonton ornithologists revealed this species to be regular, though scarce, in central Alberta.

Hawk Owl (Surnia ulula). In December an individual was seen on three occasions just west of Calgary. Like a Gyrfalcon (Falco rusticolus) then in the same area, this bird was an habitual bale-sitter. "Stooks" of bales apparently provide favorable perches from which to capture mice and voles.

Barred Owl (Strix varia). On September 5 and 6 , one was seen in Calgary (Inglewood). This is the second record for the Calgary area; a specimen was taken near the city in 1912 .

Red-shafted Flicker (Colaptes cafer). One male was seen on St. Patrick's Island, Calgary, in December; making this the third consecutive year that an individual of this species has chosen to winter there. Only rarely do flickers remain the entire winter in Alberta.

Three-toed Woodpeckers (Picoïdes spp.). Both species, Black-backed and Northern, were surprisingly common in the Calgary region from October through to December. In the past, these woodpeckers have been irregular, scarce winter visitors.

Western Kingbird (Tyrannus verticalis). A nesting pair was found in Calgary (Inglewood) early in August.

White-breasted Nuthatch (Sitta canadensis). This species was common in Calgary from September to December, inclusive. White - breasted Nuthatches, known in this area for only a few years, had formerly occurred as scarce winter visitors, of no regularity.

Brown Creeper (Certhia familiaris). On July 3, one was in southwest Cal- 
gary (Fish Creek). This fills the gap between June and August for this area, making it a "permanent resident".

Solitary Vireo (Vireo solitarius). On July 3 , a singing male was found in the Calgary Zoo grounds; a great distance south of this species' breeding grounds in the northern half of the province.

Black-and-White Warbler (Mniotilta varia). On May 23, a male was seen near the Vermilion' Lakes in Banfi National Park (Dave Thomae, pers. comm.). This would appear to be the first observation from the mountains of Alberta.

\section{[Black - throated Gray Warbler} (Dendroica nigrescens). On September 6 , a male warbler, apparently of this species, was seen in Calgary (Inglewood). It had the same general colour pattern as a Townsend's Warbler (Dendroica townsendi) except that the yellow of townsendi was replaced by white and the olive colouring replaced by grey. The bird's call note was also similar to that of townsendi. At the time of the sighting, both of us were familiar with the Townsend's Warbler and Black-and-white Warbler, species with which the Blackthroated Gray Warbler can be confused; in fact, both these species were seen the following day. We are, therefore, fairly certain of our identification. The Black-throated Gray Warbler is listed as "hypothetical" for Alberta.]

Bay-breasted Warbler (Dendroica castanea). On July 3, a male was found singing in White Spruce habitat in southwest Calgary (Fish Creek). Like the Solitary Vireo, also seen in Calgary on the same day, this species nests in central and northern Alberta. The simultaneous occurrence of two northern forest birds singing in southern Alberta in early July is puzzling.

Ovenbird (Seiurus aurocapillus). During the summer there were at least three males on nesting territories in southwest Calgary (Fish Creek). The only other place where
Ovenbirds are known to breed in southwestern Alberta is west of Turner Valley.

Yellow-breasted Chat (Icteria virens). On August 30, one was found in Calgary (Bowness Park). This seems to be the first record for Calgary proper.

Canada Warbler (Wilsonia canadensis). In Calgary (Inglewood) two were seen on August 16, two on August 17, and one on August 20. These are the only known southern Alberta records since the spring of 1966, when several were seen near Banff by members of the Calgary Bird Club.

Rose-breasted Grosbeak (Pheucticus ludovicianus). On May 30, a male was seen between the second and third Vermilion Lakes, Banff N.P. It was feeding along the roadside, but flew into a tree when approached (Dave Thomae, pers. corres.). Only rarely have Rose-breasted Grosbeaks been recorded in the mountains.

Black-headed Grosbeak (Pheucticus melanocephalus). From August 14 to 17 there was a female present in Calgary (Inglewood); on August 20, a female and a male were seen in the Calgary Zoo grounds. This species was also seen in August, 1967, at Inglewood. Just where these fall migrants are coming from is unclear; The Birds of Alberta states that in recent years, Black-headed Grosbeaks have not been recorded north of the South Saskatchewan River (more than 100 miles south of Calgary).

Purple Finch (Carpodacus purpureus). On August 14, two females or immatures were seen in the Calgary Zoo grounds. Purple Finches are scarce, irregular, migrants in Calgary and when they are seen it is usually late in September; making these individuals six weeks early. In eastcentral Alberta there were early snowfalls in August which could very likely account for this early southward movement, also observed in the warblers.

Slate-colored Junco (Junco hyemalis). Several spent the summer in southwest Calgary (Fish Creek). 
Whether or not they nested is not known, but in the light of the following record, it is quite probable. These birds were a fair distance southeast of their normal summer range.

Oregon Junco (Junco oreganus). At least one pair nesited and raised young in southwest Calgary (Fish Creek); east of the recorded nesting range in the mountains.

White-throated Sparrow (Zonotrichia albicollisQ. White-throated Sparrows are regarded as occurring only as migrants in southern Alberta; but in 1968 this species was recorded from three areas in Calgary and two northwest of Calgary. In at least two areas of Calgary young were raised. Also White-throated Sparrows were seen in the second Vermilion Lakes area (three on May 15 and one on May 8-Dave Thomae, pers. comm.Q. The only other known observation of this species from the mountains is a pair in June of 1966 at Vermilion Lakes.

Smith's Longspur (Calcarius pictus). On September 14, a male in fall plumage was seen about 45 miles northwest of Calgary. This is the only record from this area for several years.

\section{WINTER PIGEON HAWK RECORDS AT BRANDON}

by Mrs. B. A. Robinson, 1441 - 8 th Street, and Miss Mamie McCowan, 1415-8th Street, Brandon, Manitoba

Because sightings of the Pigeon Hawk (Falco columbarius) in winter months are uncommon in Manitoba, the following records made in or near Brandon during the past few years may be of interest.

January 1, 1963: one observed near the southern city limits.

February 6, 1966: a female was seen flying near the Brandon Fair Grounds with a Bohemian Waxwing in its talons (reported Blue Jay, 24: 99).

January 15, 21, 28, 29 and February 4, 1967: a female was seen in the same area of the Fair Grounds. House Sparrow feathers were often seen scattered across the snow in this locality.

February 3, 1968: one was seen about eight miles southeast of the city.

In the winter of 1968-69, although we did not see a Pigeon Hawk until late in February, on several occasions during the season we noticed House Sparrow and Bohemian Waxwing feathers on the snow in the Fair Grounds. In February 1969 a gentleman living in that neighborhood mentioned having seen a small hawk. We finally saw a Pigeon Hawk about five miles northwest of the city on February 23, 1969.

\section{PIGEON HAWK INFORMATION WANTED}

As part of my continued study of the Pigeon Hawk or merlin, I have recently sent a questionnaire regarding breeding populations in Saskatchewan and Alberta to observers in representative areas.

I was unable to locate observers for the following areas of Alberta: Red Deer River-Little Sandhill Creek, Rosebud, Tofield, and Carsland. If you live in any of these areas and have records spanning a period of 10 years or more, please contact me and I will send you a questionnaire. These are very important areas and your assistance will be greatly appreciated.

If any Blue Jay readers have nesting data for this species that have not been previously recorded in the Prairie Nest Records Scheme, this too would be greatly appreciated. If any have clutches of eggs of this species collected since 1940 I will have them weighed to see if there has been a significant change in egg shell thickness since the introduction of pesticides.

The merlin has shown a marked decline in many regions and this study is one of several being made to determine the reason for the decline, and if possible, to prevent its becoming an endangered species. YOUR COOPERATION IS NECESSARY.

Glen A. Fox, 65 Grange St., Guelph, Ontario. 